BIORHEOLOGY, 24; 279-281, 1987

$0006-355 X / 87 \$ 3.00+.00$ Printed in the USA.

Copyright (c) 1987 Pergamon Journals Ltd. Al1 rights reserved.

\title{
ANNOUNCEMENT
}

\section{FIFTH EUROPEAN CONFERENCE ON CLINICAL HAEMORHEOLOGY}

Bordeaux, France, 29 June to 1 July, 1987

The Fifth European Conference on Clinical Hemorheology will take place, as mentioned above, from 29 June to 1 July, 1987 . Its Presidents are Professor J. Boivin and Professor J.-F. Stoltz. The Chairman of the Organizing Committee is Professor Michel R. Boisseau.

The principal topics concern the relationship of haemorheological disorders to the circulation of the blood, including the microcirculation. Several symposia are being organized pertaining to the study of these clinical disorders. Pharmacological and therapeutic aspects will also be dealt with. In an effort to cover associated fields in the medical sciences, mutual sessions are being organized with French and other European Societies of Angiology, Neurology and Thrombosis.

The receipt of abstracts of communications will have to reach the Scientific Secretarial office not later than 1 March, 1987.

For any other information please contact Professor Michel $R$. Boisseau, Secrétariat Scientifique, Hôpital Cardiologique et Hémobiologie, 33604 PESSAC Cedex, France. Telephone 56362445 Telex 560349 F. 


\title{
ANNOUNCEMENT
}

\section{XIth CONGRESS OF THE INTERNATIONAL SOCIETY}

\section{ON THROMBOSIS AND HAEMOSTASIS}

\author{
BRUSSELS INTERNATIONAL CONFERENCE CENTRE (HEIZEL), 5-10, 1987
}

Meeting of the International Committee on Thrombosis and Haemostasis (ICTH) on 4-5 July, 1987. Joint Meetings of the ISTH with the European Society of Cardiology on 7-8 July, with the World Federation of Hemophilia on 9 July and with the International Society of Blood Transfusion on 9-10 July. Seven Satellite Meetings on 11 July, 1987.

*Each day of the Congress there will be 4 to 6 State of the Art Lectures on the following topics and with their respective lecturer mentioned : Platelet membrane glycoproteins and their clinical aspects (A.T. Nurden); Platelet adhesion: mechanisms and prevention (J.J. Sixma); Signal transduction in platelet activation ( $R . J$. hiaslan); Platelet contractile proteins in relation to platelet structure ( $\mathrm{J}$. Fox); The pathophysiology of fibrinolysis ( $F$. Bachmann); Clinical experience with new thrombolytic agents ( $D$. de Bono); Vascular growth factors (A. Wasteson); Antithrombotic drugs and the prevention of stroke (C. Warlow); Potential of the new heparins (J. Hirsh); Drugs interfering with platelet functions: mechanisms and clinical relavance (V. Fuster); Classification of von Willebrand's disease ( $Z$. Ruggeri); Treatment of factor VIII inhibitors (A.L. Bloom); Initiation of coagulation and relationships between intrinsic and extrinsic coagulation pathways ( J.H. Griffin); Regulation of fibrinogen synthesis (G.R. Crabtree); Platelets and coagulation (K.G. Mann); Lupus anticoagulants and thrombosis (K. Lechner); Gammaglobulin containing blood products and haemostasis: roses with thorns? (J.D. Cash); Factor VIII and IX concentrates: clinical efficacy as related to purity. Monoclonal antibody adsorbed and recombinant preparations (H.R. Roberts); Angiogenesis ( $\mathrm{J}$. Folkman); Vessel wall eicosanoid production: endothelium derived relaxing factor (S. Moncada); Septicaemia and vessel wall (G. Muiller-Berghaus); Thrombotic thrombocytopenic purpura and allied disorders (G. Remuzzi).

*Daily Plenary Session Lectures are on following topics and presented by : What has the amino acid sequence of clotting inhibitors taught us? (R.W. Carrell); The action of heparin in whole plasma (H.C. Hemker); The epidemiology of haemostatic and other risk variables factors for coronary artery disease (T.W. Meade); Molecular biology of von Willebrand factor (J.E. Sadler); Adhesive proteins: cell biology of thrombospondin (R.L. Nachman) and are followed by the presentation of an outstanding abstract on the same topic. 
* There are daily 5 simultaneous Symposia on following topics and with their respective chairpersons : Modulation of vessel wall coagulant properties (K.S. Sakariassen, D.M. Stern); The biology of megakaryocytes (J. BretonGorius, P.K. Schick); Fibrinolysis: single-chain urokinase-type plasminogen activator (biochemistry, receptors, contact activation) (V. Gurewich, H. Saito); Proteins $C$ and $S$ : structure and function (R. Bertina, B. Dahlbäck); Deep vein thrombosis (E.W. Salzman, J.C.W. van de Loo); Unstable angina and coronary artery thrombosis (E. Falk, D.G. Julian); Familial thrombosis (P.C. Comp, P.M. Mannucci); Endothelial modulation of vascular responsiveness (J.L. Gordon, P.M. Vanhoutte); New developments in fibrin-specific thrombolytic agents (D. Collen, E. Haber); Platelet receptors and inhibitory peptides (J. Hawiger, G. Marguerie); Molecular genetics of haemophilia (S. Antonarakis, E.G.D. Tuddenham); Interaction of endothelial cells with leukocytes and their products (E. Dejana, M.A. Gimbrone); Rheological aspects of thrombosis (G.D. Lowe, V.T. Turitto); Biosynthesis and posttranslational processing of the vitamin $\mathrm{K}$-dependent proteins (B. Furie, C. Vermeer); Platelets for transfusion (preparation and clinical use) (S. Murphy, C.Th. Smit Sibinga); Transfusion associated diseases in haemostasis therapy (P.H. Levine, S. Seidl); Pathogenesis and management of idiopathic thrombocytopenic purpura (D.S. Beardsley, A.E.G.Kr. von dem Borne); The role of serpins in fibrinolysis (E.K.O. Kruithof, D.J. Loskutoff); Factor VIII structure and function (D.N. Fass, C.A. Fulcher); Biochemistry of the initial stages of platelet activation ( $E$. Lapetina, M.C. Scrutton).

*Daily two parallel Lunch Sessions on Novel Techniques and Methodology are organized in collaboration with the biomedical industry.

*On 11 July, 1987 there will be 7 Satellite Symposia.

To receive the detailed programme and Registration Form, please write to: XIth ISTH Congress, c/o Centre for Thrombosis and Vascular Research, Campus Gasthuisberg, Teaching and Research, Herestraat 49, B-3000 Leuven, Belgium. 